\title{
Phytochemicals and Antioxidant of Seaweed Tea Padina Australis
}

\author{
Nandya Fitri R. ${ }^{1}$, Ika Faiz Nuryanti ${ }^{2}$, Dewi Mutamimah ${ }^{3}$, Nadya Adharani $^{4}$ \\ (Received: 10 December 2021 / Revised: 17 December 2021 / Accepted: 21 December 2021)
}

\begin{abstract}
One of the seaweeds that are widely found in Indonesia is seaweed / brown algae. An example of brown algae, one of which is Padina australis. Padina australis is a seaweed that contains many bioactive compounds, such as alkaloids, flavonoids, saponins, tannins, and antioxidants. However, Padina australis is not widely applied and used in processed food products. So in seaweed research, Padina australis is used as seaweed tea. In this study, Padina australis seaweed tea was carried out the difference in length of immersion with hot water and the treatment of immersion time is 0 minutes, 5 minutes, 10 minutes, and 15 minutes. The bioactive compounds studied are alkaloids, flavonoids, saponins, tannins, and antioxidant activity. The results showed that the difference in immersion time there are bioactive components in the form of phytomias contained in Padina australis tea, among others: alkaloids, flavonoids, tannins, and saponins in each treatment (0 minutes, 5 minutes, 10 minutes, and 15 minutes). In the test the highest antioxidant activity on P4 treatment (15 minutes) was $47.7 \%$ and for the lowest on treatment $P 2$ (5 minutes) by $\mathbf{4 4 . 8 \%}$.
\end{abstract}

Keywords — antioxidants, padina australis, phytochemicals, seaweed.

\section{INTRODUCTION}

$\mathrm{F}$ ishery catches in Indonesia are quite high, which is the catch in the form of marine life including seaweed. Seaweed or also called algae or algae is a natural resource or commodity that has a high economic value, easy to cultivate, and has low production costs. Ministry of Marine and Fisheries Regulation [1] seaweed cultivation production data in 2020 reached 10.99 million tons and in 2021 reached 11.55 million tons. The results are due to the government distributing seaweed seed aid to the community which was recorded at $200,000 \mathrm{~kg}$ in 2020 and $350,000 \mathrm{~kg}$ in 2021.

Sarwanto [2] Seaweed grows in many areas of shallow waters with sandy conditions, little mud, or a mixture of both that have inherent properties because seaweed has thallus. Good seaweed quality will be much in demand by the industry because it contains sources of caraginan, gelatin, and high alginate. It also contains bioactive compounds such as carotenoids, phenol compounds and their derivatives, polysaccharide sulfates and vitamins, as well as antioxidants.

Antioxidant compounds can come from natural compounds and synthetic compounds. However,

Nandya Fitri R. is with Fisheries Products Technology study program, Faculty of Agriculture, PGRI Banyuwangi University, Banyuwangi, 41482, East Java, Indonesia. Email nandyarachmawati@gmail.com

Ika Faiz Nuryanti is with Fisheries Products Technology study program, Faculty of Agriculture, PGRI Banyuwangi University, Banyuwangi, 41482, East Java, Indonesia. Email ikafaiznuryanti97@gmail.com

Dewi Mutamimah is with Fisheries Products Technology study program, Faculty of Agriculture, PGRI Banyuwangi University, Banyuwangi, 41482, East Java, Indonesia. Email dewimut91@gmail.com

Nadya Adharani is with Fisheries Products Technology study program, Faculty of Agriculture, PGRI Banyuwangi University, Banyuwangi, 41482, East Java, Indonesia. Email: nadya.adharani@gmail.com antioxidant compounds derived from natural compounds have an important role because they do not cause carcinogenic properties when applied to products. One of the bioactive compounds of natural antioxidants is found in seaweed, which is also the result of Indonesia's abundant fisheries and marine [3].

One of the areas in East Java Province producing seaweed is Banyuwangi. In the Banyuwangi region, seaweed developed is Eucheuma cottonii. This is because Eucheuma cottonii is easy to cultivate and has affordable capital needs. Other types of seaweed that are often found, Ulva Lactuca, Sargassum, Padina australis. Padina australis is a brown algae seaweed that is of economic value because it is useful as feed for livestock, as a supplement, fertilizer, and as an antimicrobial in the field of health [4].

Padina australis is one of the seaweeds that are widely found in the waters of Banyuwangi but has not been widely used or applied in processed products, even though Padina australis seaweed kayak will be bioactive compounds, one of which is antioxidants. According to Hidayati et al. [5] Padina autralis has the potential as a natural antioxidant and contains active compounds in it such as flavonoids, alkaloids, tannins, triterpenoids, saponins, phenolics, and pigments such as chlorophyll a, chlorophyll c, carotenoid, fucosantin, fukoxantol and $\beta$ carotene. This study aims to determine phytochemical tests and antioxidant tests of Padina australis seaweed tea with differences in length of immersion.

\section{METHOD}

In this study uses qualitative and quantitative descriptive research design. Qualitative methods to determine the phytochemical results of seaweed tea Padina australis include alkaloids, flavonoids, tannins, saponins, triterpenoids and steroids. While quantitative methods to find out antioxidant activity. Padina australis seaweed collection in Sumber Kencono village, Wongsorejo Subdistrict, Banyuwangi Regency, East Java. This study made seaweed tea Padina australis with 
a difference in immersion with hot water that is 0 minutes, 5 minutes, 10 minutes and 15 minutes.

\section{A. Analysis of Alkaloid Compounds}

Rumagit et al. [6] a total of $4 \mathrm{~mL}$ of sponge ethanol extract is inserted into the test tube then added $2 \mathrm{~mL}$ of chloroform and $5 \mathrm{~mL}$ of ammonia $10 \%$, then added 10 drops of sulfuric acid $2 \mathrm{M}$ to clarify the separation of the formation of 2 different phases. The upper part of the formed phase is taken, then added mayer reagent. The presence of alkaloids in the sample is characterized by the formation of red deposits.

\section{B. Analysis of Flavonoid Compounds}

$3 \mathrm{ml}$ of extract is put into the test tube then add $1 \mathrm{ml}$ $\mathrm{NaOH} 2 \%$ then add 10 drops of solution $(\mathrm{HCl} \mathrm{1:5).} \mathrm{If} \mathrm{the}$ extract solution is fading, it indicates the presence of flavonoid compounds [7].

\section{Analysis of Saponin Compounds}

$2 \mathrm{ml}$ of extract is put into the test tube in addition 2 $\mathrm{ml}$ of water $(1: 1)$ while shaken for 1 minute, if it causes foam, in addition, $\mathrm{HCl} 1 \mathrm{~N}$. If the foam formed can last for 10 minutes with a height of $1-3 \mathrm{~cm}$, then it indicates the presence of saponin compounds [7].

D. Analysis of Tannin Compounds
$2 \mathrm{ml}$ of extract is put into a test tube, then added with 3-5 drops of $5 \% \mathrm{FeCl} 3$ solution. If the solution produces a blackish green color or ink blue, then the material contains tannins [7].

\section{E. Antioxidant Activity Analysis}

The test solution has been made, each taken as much as $1 \mathrm{~mL}$ and reacted with a $1.5 \mathrm{~mL}$ solution of 1.1 diphenyl-2-pikrilhydrazil (DPPH) in ethanol and divortex for 2 minutes. The change in the color of the solution from purple to yellow indicates the efficiency of free radical antidotes. Furthermore, in the last 5 minutes leading up to 30 minutes of incubation, absorbance is measured at a wavelength of $520 \mathrm{~nm}$ using a UVVis spectrophotometer.

\section{RESULTS AND DISCUSSION}

A phytochemical test is a qualitative test to find out the active compounds contained in plants. The basic principle is the presence of a color tester reaction with a reaction. Phytochemical tests were conducted on seaweed tea Padina australis with a difference in the length of immersion of 0 minutes, 5 minutes, 10 minutes, and 15 minutes using $96 \%$ ethanol extract that can be seen in Table 1.

TABLE 1.

RESULTS OF PHYTOCHEMICAL ANALYSIS

\begin{tabular}{|c|c|c|c|c|c|}
\hline \multirow[t]{3}{*}{ Seaweed tea Padina australis Treatment } & \multicolumn{5}{|c|}{ Identification of Compounds } \\
\hline & \multicolumn{2}{|c|}{ Alkaloid } & \multirow[t]{2}{*}{ Flavonoid } & \multirow[t]{2}{*}{ Tanin } & \multirow[t]{2}{*}{ Saponir } \\
\hline & Mayer & Wanger & & & \\
\hline Treatment P1 (0 minute) & + & + & ++ & ++ & ++ \\
\hline Treatment P2 (5 minutes) & +++ & +++ & ++ & ++ & ++ \\
\hline Treatment P3 (10 minutes) & +++ & +++ & +++ & +++ & +++ \\
\hline Treatment P4 (15 minutes) & +++ & +++ & +++ & +++ & +++ \\
\hline
\end{tabular}

Information : $+++\quad:$ more compounds

$+\quad$ : contains enough compounds

$+\quad$ : contains compounds

- $\quad$ : not contain compounds

In the table above, the results of alkaloids in mayer reagents for $\mathrm{P} 1$ treatment ( 0 minutes) are seen in the treatment containing alkaloid compounds in the presence of brown deposits. In the treatment of P2 (5 minutes), treatment P3 (10 minutes), and treatment P4 (15 minutes) seen the presence of enough chocolate deposits in the extract of seaweed tea Padina australis. While the results of alkaloids in Mayer reagents on P1 treatment (0 minutes) are seen in the treatment contains alkaloid compounds in the presence of white deposits. In the treatment of P2 (5 minutes), P3 treatment (10 minutes) and $\mathrm{P} 4$ treatment (15 minutes) there is a considerable white precipitate. In general, the form of alkaloids is in the form of crystals called alkaloid salts. The content of active chemicals in plants include primary metabolite compounds and secondary metabolites such as alkaloids, terpenoids, steroids and flavonoids [8].

In the analysis of flavonoid compounds, the results obtained flavonoid results in the treatment of P1 $(0$ minutes) and P2 treatment (5 minutes) seen in the treatment contains flavonoid compounds in the presence of a slightly faded discoloration. In the treatment of P3 (10 minutes) and $\mathrm{P} 4$ treatment (15 minutes) there was more alkaloid compounds with discoloration in the tea extract of seaweed tea Padina australis. According to Soamole et al. [9] if in a plant extract contained many flavonoid compounds, flavilium salts will be formed when added $\mathrm{Mg}$ and $\mathrm{HCl}$ that are red or orange. Secondary metabolite compounds are widely used as antioxidants, anti-inflammatory, antipirutic and antimicrobial, especially for phenolic compounds, flavonoids, and alkaloids.

In the analysis of tannin compounds, it can be seen in the treatment of P1 ( 0 minutes) and P2 treatment (5 minutes) seen in the treatment contains tannin compounds with enough with the occurrence of discoloration to green. In the treatment of P3 (10 minutes) and P4 treatment (15 minutes), there is more tannin compounds with a change of color to blackishgreen in the extract of seaweed tea Padina australis. Tannins can be divided into two groups that give different color reactions to $\mathrm{FeCl} 3$. There are hydrolysis tannins that will produce a blackish-blue color and 
condensation tannins that will produce a blackish green color. Tannins have complex biological roles ranging from protein tapping to metal lilating. Tannins can also serve as biological antioxidants [10].

In the analysis of saponin compounds, it can be seen in the treatment of P1 ( 0 minutes) and the treatment of P2 (5 minutes) seen in the treatment containing saponin compounds with the formation of foam. In the treatment of P3 (10 minutes) and P4 treatment (15 minutes) it is seen that it contains saponin compounds with the formation of enough foam in the extract of seaweed tea Padina australis. In principle for saponin testing, the hydrolysis reaction of saponin compounds into aglicon and glycon is characterized by the formation of a stable foam. Saponins are compounds that have hydrophobic and hydrophilic groups. Saponins are glycosides that have aglicon in the form of steroids and triterpenoids. Saponins have various glycosyl groups that are bound to the $\mathrm{C} 3$ position, but some saponins have two sugar chains attached to positions C3 and C17 [11].

Antioxidant activity in a sample is related to the content of bioactive compounds that the sample has. Polyphenol compounds are found in brown seaweed. The results of the antioxidant activity of seaweed tea Padina australis can be seen in Figure 1.

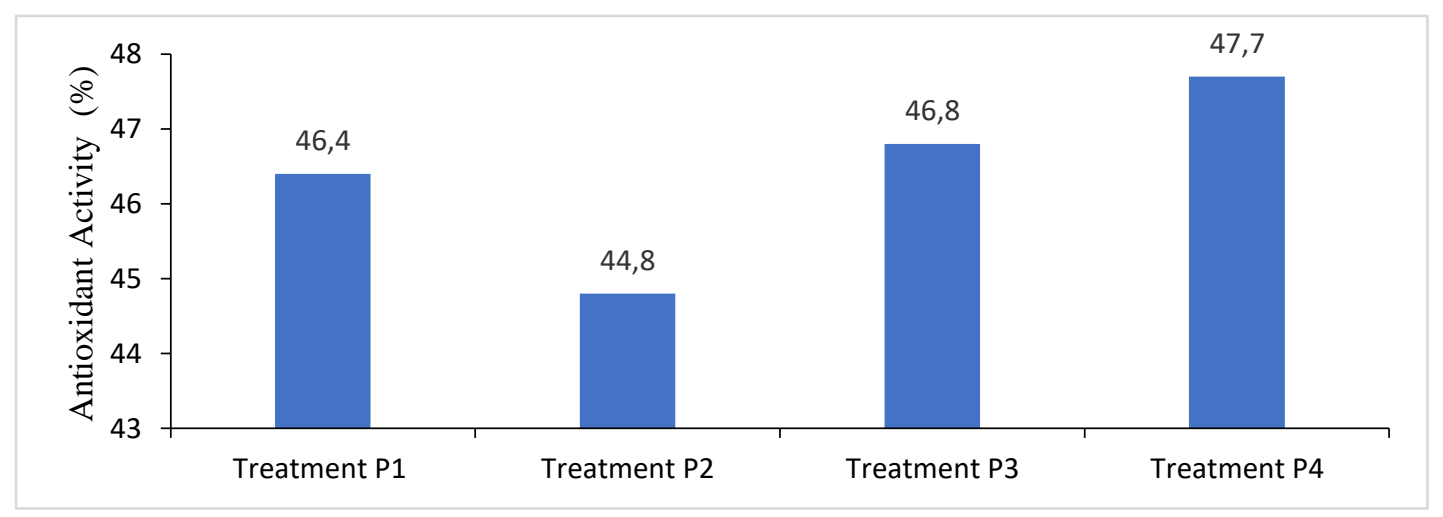

Figure. 1. Antioxidant Activity Results of seaweed tea Padina australis

The highest antioxidant content was produced by samples soaked at P4 treatment by $46.7 \%$, and the lowest antioxidant content was produced in samples soaked at P2 treatment by $46.2 \%$. The low treatment used in the immersion process causes the levels of antioxidants produced by seaweed tea Padina australis to decrease. The function of antioxidants is to prevent and extend the shelf life of food products from damage caused by oxidation. Brown seaweed has been shown to have bioactive compounds that are efficacious as antioxidants. One of the factors that affect antioxidant ability is temperature. The temperature of raw material preparations also affects the power of antioxidants. Rosella extract fresh raw materials higher antioxidant activity than from dry ingredients. That seaweed is also known to have a function as a functional food source because it has a high antioxidant content and is needed by the body. Antioxidant function can inhibit the growth of free radicals that can cause a source of disease for the human body. In addition, seaweed also serves to increase endurance, anticancer, prevent premature aging and maintain skin smoothness [12].

\section{CONCLUSION}

The results showed that the difference in immersion time there are bioactive components in the form of phytomias contained in Padina australis tea, among others: alkaloids, flavonoids, tannins and saponins in each treatment ( 0 minutes, 5 minutes, 10 minutes, and 15 minutes). In the test the highest antioxidant activity on P4 treatment (15 minutes) was $47.7 \%$ and for the lowest on treatment P2 (5 minutes) by $44.8 \%$.

\section{ACKNOWLEDGMENT}

The authors thank Jember State Polytechnic Food Analysis Laboratory for helping the authors in completing their research.

\section{REFERENCES}

[1] Peraturan Menteri Kelautan dan Perikanan, "Rencana Strategis Kementerian Kelautan dan Perikanan Tahun 2020-2024," Menteri Kelautan dan Perikanan Republik Indonesia, 2020.

[2] Sarwanto, Catur, "Peluang Usaha dan Investasi Rumput Laut," Direktorat Usaha dan Investasi Ditjen Penguatan Daya Saing Produk Kelautan dan Perikanan Kementerian Kelautan dan Perikanan, 2019.

[3] Firdiyani, Fiya., Tri Winarni A., Widodo Farid M., "Ekstraki Senyawa Bioaktif Sebagai Antioksidan Alami Spirulina platensis Segar Dengan Pelarut Yang Berbeda," JPHPI Vol 18 (1) : 28-37, 2015.

[4] Haryani,Tri Saptari, Triasinurmiatiningsih, Weni Ardiani, "Efektivitas Ekstrak Padina australis Sebagi ANtibakteri Vibrio cholera dan Salmonella tphyi”, Ekologia Vol. 15 (2) : 16-20, 2015.

[5] Hidayati, Jelita Rahma., Ali Ridlo dan Rini Pramesti, "Aktivitas Antioksidan Ekstrak Rumput Laut Padina sp. Dari Perairan Bandengan Jepara Dengan Metode Transfer Elektron," Buletin Osenografi Marina Vol 6 (1) : 46 - 52, 2017.

[6] Rumagit, Hanna M., Max R.J. Runtuwenw, Sri Sudewi, "Uji Fitokimia dan Ujia Aktivitas Antioksidan dari Ekstrak Etanol Spons Lamellodysidea herbacea," Jurnal Ilmiah FarmasiUNSRAT Vol 4 (3) : 183-192, 2015.

[7] Khoiriyah. S., "Uji Fitokimia Dan Aktivitas Antibakteri Fraksi Etil Asetat, Klorofom Dan Petrolium Eter Ekstrak Metanol Alga Coklat Sargasum vulgare Dari Pantai Kapong Pamekasan Madura," Fakultas Sains Dan Teknologi Universitas Islam Negri (UIN) Maulana Malik Ibrahim Malang : 46-47, 2017.

[8] Nuraini, Asriani Ilyas dan Iin Novianty, "Identifikasi Dan Karakterisasi Senyawa Bioaktif Antikanker Dari Ekstrak Etanol Kulit Batang Kayu Bitti (Vitex Cofassus)," Al Kimia : 15- 27, 2018.

[9] Soamole, H. H., Sanger, G \& Harikedua, D. S., "Kandungan 
International Journal of Marine Engineering Innovation and Research, Vol. 6(4), Dec. 2021. 255-258

(pISSN: 2541-5972, eISSN: 2548-1479)

Fitokimia Ekstrak Etanol Rumput Laut Segar (Turbinaria sp., Gracilaria sp., Dan Halimeda macroloba),” Jurnal Media Teknologi Hasil Perikanan, Vol. 6(3), 96-97, 2018.

[10] Liberty, P Malangingi., Meiske S. Sangi., Jessy J. E. Paendong., "Penentuan Kandungan Tanin dan Uji Aktivitas Antioksidan Ekstrak Biji Buah Alpukat (Persea americana Mill.)," Jurnal MIPA UNSRAT Online Vol 1 (1) : 5-10, 2012.

[11] Yanuartono, H. Purnamaningsih, A. Nururrozi dan S. Indarjulianto., "Saponin : Dampak terhadap Ternak (Ulasan)," Jurnal Peternakan Sriwijaya Vol 6 (2) : 79-90, 2017.

[12] Hastuti, Ningrum D, "Pembuatan minuman fungsional dari maru dan ekstrak rosella (Hibiscus sabdariffa Linn.),” Jurnal Teknologi Pangan. 3(1):29-63, 2012. 